\title{
SHELL MATRIX PROTEINS - A POTENTIAL TOOL FOR INVESTIGATING THE PHYLOGENETIC RELATIONSHIPS OF THE ECHINODERMATA
}

POLSON*, Emma S., Dept. of Biology, University of South Florida, 4202 East Fowler Ave., Tampa, Fl 33620, USA.; LAWRENCE, J., Dept. of Biology, University of South Florida, 4202 East Fowler Ave., Tampa, F1 33620, USA.; ROBBINS, L. L., Dept. of Geology, University of South Florida, 4202 East Fowler Ave., Tampa, Fl 33620, USA.

The phylogenetic relationships of the echinoderms remains controversial due to the traditional use of morphological characters which do not reflect convergent evolution. While biochemical techniques and DNA analysis may be used in addition to morphological characters for analysis of living echinoderms, these tools cannot be extended to fossils. Shell matrix proteins-of echinoderms may be trapped and preserved for millions of years in fossil genera.

Analysis of shell matrix protein from Astropectin irregularis, Luidia clathrata and Mellita tenuis, reveal the presence of at least three major proteins of approximate molecular weights 230,83 and $17 \mathrm{kDa}$ common to all species. Astropectin irregularis showed four additional major bands of molecular weights $150,90,52$ and $35 \mathrm{kDa}$ along with at least 12 minor bands. Luidia clathrata showed five additional major bands of molecular weights $99,60,40,24$ and $21 \mathrm{kDa}$ and at least 13 other minor bands. Mellita tenuis showed three additional bands of molecular weights 115,96 , and $24 \mathrm{kDa}$ along with at least 4 minor bands.

As the three common proteins have been found in both seastars (A.irregularis and L.clathrata) and echinoids (Mellita tenuis), further analysis of these shell matrix proteins may be used to elucidate phylogenetic relationships within the Echinodermata. In addition homoplasies may be identified and phylogenetically reassessed. 